\title{
The Problem of Portraying Motion in Painting and Graphic Art of the 1920s in the Context of the Theme of Sports
}

\author{
Natal'ia V. Malevinskaia* \\ Repin St. Petersburg State Academic Institute of Painting, \\ Sculpture and Architecture \\ 17 Universitetskaya Embarkment, St. Petersburg, 199034, Russia
}

Received 22.03.2016, received in revised form 21.05.2016, accepted 19.09.2016

The article covers the brightest sculpturesque solutions of the works of art of the 1920s devoted to the sport subject referring to the problem of expressing motion in painting and graphics. The lost and little-known works which had an essential impact on the formation of the genre but insufficiently examined by Russian Art Studies shall be regarded. And in particular, peculiarities of the pictures' design of such masters as A. Deyneka, Yu. Pimenov, K. Vyalov and others. The most extraordinary solutions of the problem of graphic expression of movement were proposed by representatives of Moscow Higher Art and Technical Studios (VHUTEMAS), having addressed the dynamic sports plots. Plurality of the points of view and representation of the movement in various phases often express the dynamism of the object in art works; diagonal compositions with emphasis on geometrism are also used. Having consolidated formal and analytical approach to the form and realistic vision of life and having assimilated traditions of new trends of the beginning of the 20th century, the VHUTEMAS representatives reconceived the expressiveness of composition in the easel painting.

Keywords: Soviet art of the 1920s, sports theme, motion, composite structures.

DOI: 10.17516/1997-1370-2016-9-12-2964-2970.

Research area: art history, culture studies.

\section{Introduction}

The steady and increasing public interest in the sport subject in the art of the Soviet period approves the relevance of article which also is testified by a number of retrospective exhibitions organized in Russia or abroad during preparation and in the course of the $22^{\text {nd }}$ Olympic Winter Games in our country. Art critics had an opportunity to reconstruct and study the ways of development of the Soviet art in which the subject of youth and physical health was one of the leading ones. Unfortunately, the domestic Art Studies are limited to mentioning the research of the subject of sport of the 1920-1930s in fundamental works of the Soviet art or to covering this theme in articles which are generally accompanying catalogs of exhibitions of the corresponding trend. Considering the ways of development of the sport subject, authors often disregard issues of emergence and formation of the painting

C) Siberian Federal University. All rights reserved

* Corresponding author E-mail address: malevinsckaja.nat@yandex.ru 
language, search of new image-bearing and figural idioms of compositions. As a result, there is a need to continue art search in the context of the sport subject that will enrich understanding of all completeness of this art phenomenon. The purpose of this article is to study works on the sport subject of the 1920 s which analysis will result in detection of trends and characteristics of works' compositions. This publication covers the brightest and dynamic sculpturesque solutions of the problem to express the movement by graphic means.

\section{Sport subject in the context}

\section{of studying the "function of movement"}

The order of the day for sports as a phenomenon appears at the end of the $19^{\text {th }}$ century irrespective of social changes. As first sports associations and schools start to form, it becomes mass and sensational, and since 1896 the Olympic Games revive. In 1920s-1930s the physical culture and sports are perceived already as important components of the state policy of the Soviet country. Choreography and theatre actively develop sports plots that organically transmit feeling of vital dynamics and precipitancy.

In the 1920s both representatives of creative professions and science - physiologists, economists, sociologists - undertook an attempt to theorize an issue of the movement and its capturing. The staff of the Choreologist Laboratory of the State Academy of Fine Arts in which the ideas of the artist V. Kandinsky found their reflection, worked on the search of the esthetic component of movement. His analytical drawings of 1925 represent a striking example of numerous searches for new art tools to express the movement on paper or on the canvas in the first third of the $20^{\text {th }}$ century. "It is necessary to establish connection between the movement of lines and the movement of a human body in general and in its parts: to transmit the line into the movement of the body and the movement of the body into the line. Such observations should be registered both in words and graphically", V. Kandinsky wrote in 1920 (Kandinskii, 2008: 56).

As "searching for the functions of movement" (Fedorov-Davidov, 1925), among art works on sport subject of the 1920 s, critics of that time noted paintings belonging to the masters of the art association "The Easel Painters Society" (OST): Yu. Pimenov, A. Deyneka, S. Luchishkin, K. Vyalov, etc. The outstanding art critic Ya. Tugendkhold wrote: "Besides keen interest in urbanism and technicism, there is also the second stream in the subject of OST. It is the movement area: scenes and types of sports life, physical culture, circus" (Tugendhold, 1987: 210).

The sport subject in the context of studying the "function of movement" in the 1920s wasn't limited to creativity of the OST, in the same course a great number of other masters worked. The works of the "left" trend representatives can be an example: "Fighters" by A. Rodchenko; photo collages by G. Klutsis, L. Lissitsky. At the same time masters of the Leningrad school A. Pakhomov, A. Samokhvalov, V. Lebedev also turned to this subject. This theme also captured the attention of the graduates of the Moscow Higher Art and Technical Studios (VHUTEMAS; since 1927 - the Higher Art and Technical Institute -VHUTEIN), who did not enter the OST: K. Redko, I. Kuleshov, S. Markin, etc.

In search for the motives "...metaphorically connecting experience of space and movement" modern art studies analysts see reflection of the stock mythologem of the Soviet country, "a light way" (Morozov, 1995: 86). The art critic A. Borovsky, comparing interest of artists in transmitting the movement, dynamics in postrevolutionary years with creativity of masters of the beginning of the $20^{\text {th }}$ century, notes "appropriation" by the Soviet authors of 
other practices and achievements (Borovskii, 2001: 35).

This article pays attention to the brightest and most dynamic sculpturesque solutions of the sport subject of the 1920s of representatives of the Moscow school VHUTEMAS. Unfortunately, many of the paintings and graphic works considered by the author are lost and known only according to the description or photos.

\section{Composition of paintings devoted to sports of VHUTEMAS-VHUTEIN graduates}

The subject and spatial concept of the youth group of the OST in many respects had been developing under the influence of the innovative school of VHUTEMAS reflecting both art principles of avant-gardist teachers and P. Florensky and V. Favorskiy's theoretical and philosophical theses. Indeed, early works of A. Deyneka mostly express the idea of his teacher V. Favorskiy about structural evolution of forms and of the ability to represent "occurring at different space and at different times" in one plane. We can see this in the representation of consecutive phases of the movement of the human body in the panelpainting "Soccer" (1924) and the homonymous graphics of 1923. The artist consolidates life observations and the theoretical knowledge of composition acquired at the institute. In the graphic sheets "Tennis" (1923), "Soccer" (1923), "Fencing" (1923) the plane subordinates the rhythms of composition. The art expression is reached by the smart sculpturesque solution and the cold constructive analysis of forms, thus the constructibility does not disappear in any way, and on the contrary, is an esthetic dominant. Almost in all cases, the artist resorts to the closed composition in a format approached to a square and fills the space with large-scale figures what is usually used to express something steady and static. But the impression of firmness only

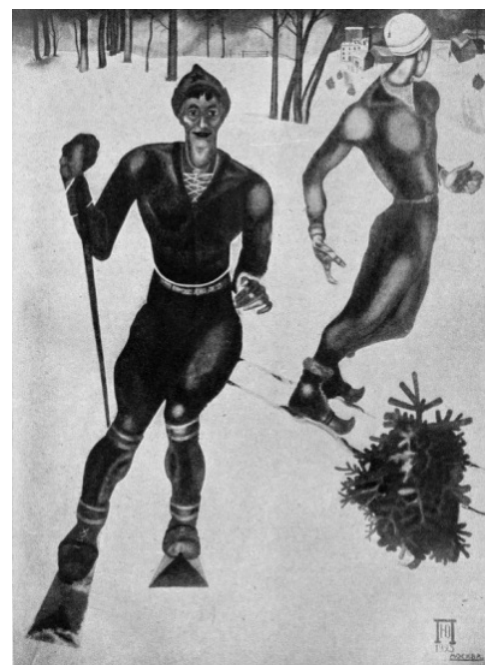

Fig. 1. Yu. Pimenov. "Skiers". 1925

strengthens the internal intense dynamics of multidirectional lines.

Along with A. Deyneka the problem of expression of the movement in a sports plot was captivated his fellow student Yu. Pimenov. Almost all his pictures of this genre feature diagonal construction, a close up, restriction of space round characters. They possess both constructivist heritage, emphasized dynamics of forms, a graphic-linear basis of composition, and an expressionist emotionality. "Boxing" (1924) and "Skiers"(1925)(Fig. 1.) are the earliest works of "the sports cycle" of Yu. Pimenov. The art critic A. Fedorov-Davydov noted the latter as possessing "the greatest dynamism", excellent "as by that expression skiers slide with, and by the general extremely vigorous and fresh impression of life it leaves" (FedorovDavidov, 1925). Dark silhouettes of the athletes who are climbing down a mountain stand out for their contrast with a light background of snow. Axial guides of the figures set spatial dynamics. Despite alleged splitting sliding, the bodies of athletes are stiffened in accurately fixed turns. Angularity, deformation of forms, grotesqueness give emotional expressiveness 


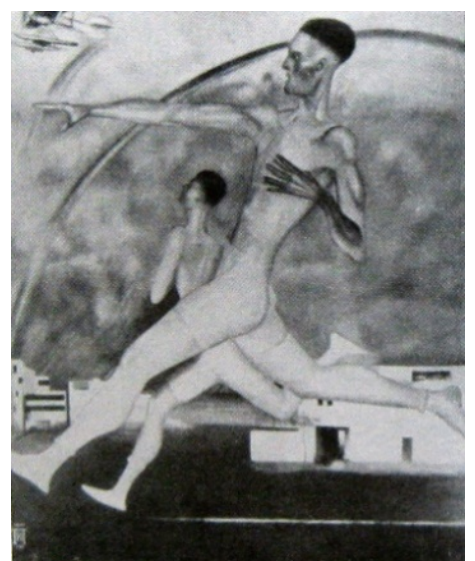

Fig. 2. Yu. Pimenov. "Run”. 1928

to the figures. The appeal to graphic means of the German expressionism for which the OST had been blamed more than once, in this case corresponds to the subject. We consider laconicism, the raised effusiveness, hyperboles, impetuosity and even a physiologism to be the best artistic techniques to transmit of the atmosphere of physicality, precipitancy of the movement.

Yu. Pimenov employs the same composition scheme, as in "Skiers", in the work "Skating Rink" (1926): diagonal construction, use of the high horizon, combination of two large-scale figures, one full face, another, remote - in a turn. The movement is the only thing that changes. The skater in the forefront is more statical, with the hands put on her breast. The seeming stability and tranquility of the girl in the forefront contrasts with the developed sliding of the second sportswoman coming nearer to the viewer. The artist experiments with the form "occurring at different times"; if in "Skiers" the remote figure is turned in the direction deep into the canvas and she looks at the horizon, in "Skating Rink" both girls are directed to the viewer. One often meets open contrast between the forced movement of one character and tranquility of the second, with the figures removed at the forefront, in works of
A. Deyneka, for example, in "Skiers" executed in gouache (the $2^{\text {nd }}$ half of the 1920s).

One can find an easeful situation of physicality against an industrial landscape in paintings of Yu. Pimenov “Tennis" (1926), "Run” (1928) (Fig. 2.). In both cases, the artist resorts to the lateral image of the figures occupying almost all space of the canvas. In "Tennis" he breaks the composition diagonally into two triangles and enters the image of the girl standing close by in one of them. The canvas frame cuts off the figure of the second tennis-player dynamically passing a ball to the opponent. Yu. Pimenov exaggerates shapes of the bodies, revealing the muscular force, bringing erotic notes thanks to which a bright image of a modern sportswoman appears.

The painting "Run" represents two largescaled men striving for the finishing line at the moment of the ultimate tension. The horizontal line of the hand thrown forward strengthens the prompt movement of the first figure. A typical gesture and anatomic features of draughtsmanship of the athlete's muscles remind Zh. Gudon's ecorche finding out neoclassic traces. The detailed drawing of the model helps the artist to express the character of the main form more clearly. Behind purely "physiological", "pathological" picture the aspiration of the master to transmit the rhythm of the movement, an expression of gestures, run of new times reveals itself.

In the graphic "Start" by Yu. Pimenov the composition takes the form of forward motion from one edge to another. The main principle of the composition is a rhythm. The line of athlete figures in strong foreshortening transforms into the isosceles triangle manifesting itself sculpturesque abstraction of the work. Exaggeratedly extended, skeletal figures of swimmers are drawn schematically, with violation of proportions and distortion of anatomy. All attention of the artist is concentrated on consecutive reduction 


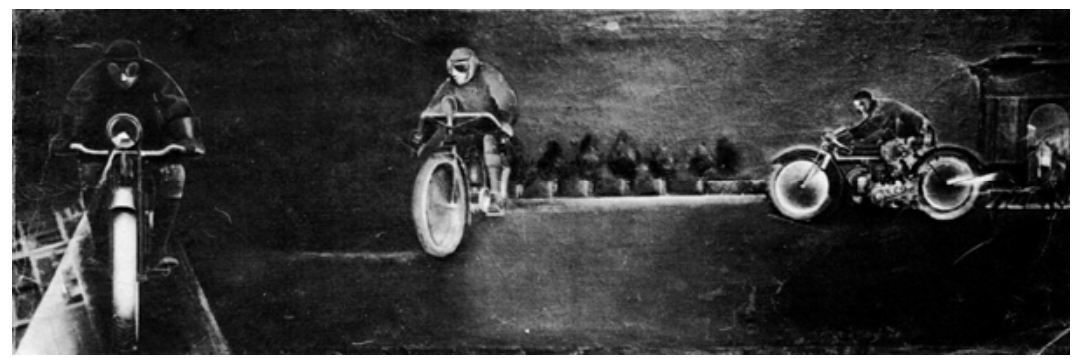

Fig. 3. K. Vyalov. “Motorcycle Run”. 1925

and alternation of elements to strengthen the dynamics of the perspective line.

However, the works of artists appeared not only due to the influence of the bone-dry theoretical doctrine. A brand-new view of reality, its representation in new expressive and dynamic or panoramic foreshortenings could not but have an impact on creativity. Almost all contemporaries of A. Deyneka and Yu. Pimenov faced the problem of "the new world" as a problem of acquisition of a technocratic utopia of the Soviet country. In K. Vyalov's work “Motorcycle Run" (1925) (Fig. 3.) a man and a vehicle complement each other harmonically. The motorcyclist's protective equipment with metal shimmer brings a futuristic note to the image of the racer uniting the person and technical object in a whole. Certainly, the era of the cinema had an impact on the representation of the movement. The fragmentariness of composition decisions gains another character than in previous years. The movie camera shoots not simply a life instant like a photo, but millions of instants in their consecutive movement. This insuperable charm of the cinema one can find in K. Vyalov's work. "Motorcycle run" is a bright example of an image developed in a chronological sequence. The horizontal glaring lines of the road with variously spaced motorcyclists create a peculiar stepped composition in which the average link (the central racer) serves as a binding diagonal of the first and far distance view. A cyclic rhythm of

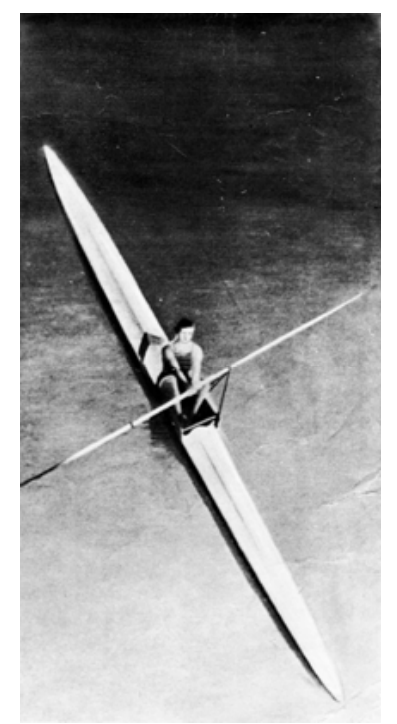

Fig. 4. K. Vyalov. "Start. Aquatics". 1928

the change of motorcycles' wheels accompanies the turns of figures in time from a frontal circle to the lateral line. In fact, it is a shot breakdown of the movement of one racer, representation of one and the same plot from different points of view.

In K. Vyalov's works of the OST period one can also feel the heritage of his creation of the beginning of the 1920s when he belonged to the circle of VHUTEMAS youth, keen on science and art connection theory. For example, K. Vyalov's work "Start. Aquatics" (1928) (Fig. 4.) with its laconicism and geometry, reminds us of the analytical painting of artists-projectionists. The canvas represents a certain moment preceding the movement, one second before the start. The 
contrast between figurally dynamic composition and static image is clearly expressed. The canvas is vertical, the geometry of crossing diagonals of an oar and a kayak create a huge internal tension in comparison with the stiffened oarsman's figure.

A series of graphic sheets "Let it be a healthy change!" (1929) executed by the VHUTEMAS member I. Kuleshov is interesting due to the sculpturesque solution. Its colourful lithographs with the rushing hockey players, skiers, jumping swimmers reveal a stylistic proximity with creativity of the OST, but they lose rigidity and create an impression of easy and fast water colour etudes. The artist offers a non-standard composition creating a complex dance of crossing bodies of athletes, ski or hockey sticks.

\section{Conclusion}

Thus, the works on the sports subject by the artists most concentrated on studying “ the function of movement" considered in this article, allow to estimate the innovative (for its time) approach to the composition structure of works. Undoubtedly, the general climate in the art world of the 1920s directly influenced the way of thinking of artists, promoted the creative thought. According to the research, the artists addressed to dynamic sports motives to study purposefully the possibility of graphic capturing of the movement. The representatives of the Moscow school VHUTEMAS solved this problem brightly, having addressed the dynamic sports plots in an extraordinary way. Having united the formal and analytical approach to the form acquired during the studies with the realistic life vision and having assimilated traditions of new trends that had appeared at the beginning of the century they came to absolutely new understanding of composition expressiveness in the easel painting.

In a number of works of VKHUTEMAS artists, the constructive analysis of forms in combination with fineness of the sculpturesque solution and expressionist emotionality of works acts as an esthetic dominant. Quite often the movement of the object expresses itself in plurality of the points of view of capturing it at various phases. Compositions with a diagonal construction or an emphasis on a geometrism reveal the use of some tricks peculiar for constructivist esthetics. Due to precisely directed lines and the just proportion of masses, the figural interrelation of the statics and the movement creates surprising harmonious compositions in the structure of works.

\section{References}

Aleksandr Deineka (1989). Sbornik. In 2v. [Aleksandr Deineka. Collection in 2 v.]. V. 1. Sisoev, V.P. Monografiya [Monograph]. The Scientific Research Institute of the Theory and History of Fine Arts of the Acad. Of Fine Arts of the USSR. Moscow, Visual Art. 328 p.; V. 2. Zhizn, iskusstvo, vremya. Literaturno-hudozhestvennoe nasledstvo [Life, art, time. Literary and artistic legacy]. / compiled by V.P Sisoev. The Scientific Research Institute of the Theory and History of Fine Arts of the Academy Of Fine Arts of the USSR. Moscow, Visual Art, 1989. 296 p.

Borovskii, A. (2001) Cep romanov. Russkoe iskusstvo proshedshego veka. Nezanudlivii kurs [Chain of novels. Russian art of last century. Not boring course]. St. Petersburg, ERVI, 2001. 208 p.

Fedorov-Davidov A. (1925). On exhibitions The press and revolution (5-6) pp. 257-276.

Zherdeva, R. (1983). The origins of the sports theme in the visual arts. Art (4), pp. 33-39. 
Kandinskii, V.V. (2008) The schematic program of the Institute of Artistic Culture according to the plan of V. V. Kandinsky. Izbrannie trudi po teorii iskusstva: $v 2 t$. [Selected works of the theory of art: in 2 v.]. Moscow, Gileya. T. 2. 1918-1938, pp. 53-74.

Luchishkin, S.A. (1988) Ya ochen lyublyu zhizn Stranitsi vospominanii [I love life Pages of memories]. Moscow, Soviet artist. $254 \mathrm{c}$.

Misler, N. (2011) V nachale bilo telo. Ritmoplasticheskie eksperimenti nachala XX veka. Horeologicheskaya laboratoriya GAHN [In the beginning was a body: rhythm-plastic experiments of the beginning of the XX century: Choreologist laboratory of the State Academy of Fine Arts.]. Moscow, Art-XXI century. 447 p.

Morozov, A.I. (1995) Konets utopii. Iz istorii iskusstva v SSSR 1930-h gg. [End of utopia. From the art history in the USSR of the 1930th]. Moscow, Galart. 224 p.

Tugendhold, Ia.A. (1987) Art and the present. Iz istorii zapadno evropeiskogo russkogo $i$ sovetskogo iskusstva [From the history of the West European and Soviet Art]. Moscow, Soviet artist. pp. 208-215.

\section{Проблема передачи движения в живописи и графике 1920-х гг. в контексте темы спорта}

Н.В. Малевинская

Санкт-Петербургский государственный академический институт жсивописи, скульптуры и архитектуры имени И.Е. Репина РАХ

Россия, 199034, Санкт-Петербург, Университетская набережная, 17

В статье освещаются наиболее яркие пластические решения художественных произведений спортивной тематики 1920-х г2., раскрывающие проблему передачи движения в живописи и графике. Рассматриваются утраченные и малоизвестные работы, оказавшие существенное влияние на формирование темы, но недостаточно изученные отечественным искусствознанием. Внимание акиентируется на композиционых особенностях картин таких мастеров, как А. Дейнека, Ю. Пименов, К. Вялов и др. Сделан вывод о том, что самые неординарные решения проблемь графической фиксации движения предложили представители московской школь ВХУТЕМАС, обратившись к динамичным спортивным сюжетам. В композициях художников часто движение объекта выражается множественностью точек зрения и его изображением в различных фазах, также используются диагональные построения с акиентом на геометризм. Объединив формально-аналитический подход к форме с реалистическим видением натуры и ассимилировав традици новых течений начала ХХ века, вхутемасовиь пришли к новому пониманию композиционной выразительности в станковой картине.

Ключевые слова: советское искусство 1920-х г2., спортивная тема, движение, композиционные построения.

Научная специильность: 17.00.00-искусствоведение, 24.00.00-культурология. 